\title{
Vertebral Çökme Kırıklarında Vertebral Korpusu Çökme Derecesinin Radyolojik ve Biyokimyasal Ölçüm Parametreleri ile Değerlendirilmesi
}

\section{The Evaluation of Radiological and Biochemical Measurement Parameters of the Degree of Collapse of the Vertebral Body in Vertebral Compression Fractures}

\author{
Hüseyin ÖZEVREN 1 (D) , Salih HATTAPOĞLU ${ }^{2}(\mathbb{D})$, Murat BALOĞLU ${ }^{3}(\mathbb{D})$, Muhammed Akif DENIZ 2 (D)
}

1 Dicle Üniversitesi Tıp Fakültesi, Beyin ve Sinir Cerrahisi Ana Bilim Dalı, Diyarbakır

2 Dicle Üniversitesi Tıp Fakültesi, Radyoloji Ana Bilim Dalı, Diyarbakır

3 SBÜ Gazi Yaşargil Eğitim ve Araştırma Hastanesi FTR Kliniği, Diyarbakır

Öz.

Amaç: Bu çalışmanın amacı, retrospektif olarak çökme kırığı olan hastaların başlangıç ile altıncı ay takiplerindeki radyolojik bulgularını ve kan biyokimyasal değerlerini analiz etmektir.

Materyal ve Metod: Haziran 2014 ile Aralık 2018 tarihleri arasında takipli 70torakolomber çökme kıık olgusu retrospektif olarak değerlendirildi. Herhangi bir yaş ve cinsiyet ayrımı yapılmayıp, sadece multipl çökme kıııkları, enfeksiyonlar ve metastazlar çalışma dışında bırakıldı. Radyolojik ve biyokimyasal veriler retrospektif olarak kayıt edildi. İstatistiksel olarak analiz edildi.

Bulgular: 70 torakolomber omurga çökme kırık olgusu retrospektif olarak değerlendirildiğinde vakaların 41'i $(53,68 \pm 19,27)$ erkek, $29^{\prime} ı(61,1 \pm 16,87)$ kadındı. Ortalama yaş $56,76 \pm 18,56(14-98)$ idi. Erkek ve kadınlar arasında erkeklerin sayısı fazla olmakla birlikte, istatistiksel açıdan karşılaştırdığımızda anlamlıık bulunmadı $(p=0,09)$. İleri yaşlarda ise kadınlarda sık görülmekteydi. Torakolomber çökme kırıkları sıkıkla T11-L2 düzeyinde görüldü. Vakaların başlangıç kifoz açıları $(10,56 \pm 6,97)$ ile altıncı ay kifoz açıları $(12,25 \pm 7,47)$ karşılaştıııldığında, istatistiksel açıdan anlamlı bulundu ( $p<0.001)$. Biyokimyasal değerler kendi aralarında pozitif yönde korele iken, yaş ile albumin değerlerinin negatif yönde korele olduğu görüldü. Kifoz açısı ile yaş, biyokimyasal değerler arasında anlamlı korelasyon görülmedi.

Sonuç: Çalışmamızda torakolomber omurga çökme kırıklarında zamanla kifoz açısının arttığını gördük. Bu durum yaş ve kan biyokimyasal değerlerinden total protein, albumin, kalsiyum ile ilişkili olmadığı görüldü

Anahtar kelimeler: Çökme kııı̆ı, Kifoz açısı, Omurga

Abstract

Background: The aim of this study was to retrospectively analyze the radiological and blood biochemical values of patients with collapse fractures at initial and sixth month follow-up.

Materials and Methods: Seventy thoracolumbar collapse fractures followed between June 2014 and December 2018 were evaluated retrospectively. Age and gender were not discriminated against multiple collapse fractures, infections and metastases were excluded. Radiology and biochemical data were recorded retrospectively. Statistical analysis was performed.

Results: When 70 thoracolumbar spine collapse fractures were evaluated retrospectively, 41 (53.68 \pm 19.27$)$ were male and $29(61.1 \pm 16.87)$ were female. The mean age was $56.76 \pm 18.56(14-98)$ years. Although the number of males was higher when men and women were compared, no statistically significant difference was found $(p=0.09)$. It was frequently seen in older women. Thoracolumbar collapse fractures were frequently occurring at T11-L2 level. Initial kyphosis angles (10.56 \pm 6.97$)$ and sixth month kyphosis angles (12.25 \pm 7.47$)$ were compared statistically $(\mathrm{p}<0.001)$. While biochemical values were positively correlated with each other, age and albumin were correlated negatively. No significant correlation was found between age and biochemical values when compared with kyphosis angle.

Conclusion: In our study, we observed that the kyphosis angle increases with time in fractures of the thoracolumbar spine collapse. This condition was not associated with age and blood biochemical values of total protein, albumin and calcium.

Key words: Collapse fracture, Kyphosis angle, Spine
Sorumlu Yazar I

Corresponding Author

Dr. Hüseyin ÖZEVREN

Dicle Üniversitesi Tıp Fakültesi, Beyin ve Sinir Cerrahi Kliniği, 21280, Diyarbakır, Türkiye

e-mail: drozevren@gmail.com

Tel: +905052780090

Geliş tarihi / Received: 17.10.2019

Kabul tarihi / Accepted: 18.12.2019

DOI: $10.35440 /$ hutfd. 634131 


\section{Giriş}

Kemikler devamlı yapım ve yıkım halinde olup, bu döngü sayesinde sürekli yenilenirler. Bu yenilenmede rol alan total protein, albumin ve kalsiyumun yanı sıra kemiğin damarsal beslenmesi de önemlidir. Bunlardan herhangi birinin patolojisinde kemik kitlesi ve kemik dokusu mikro yapısının bozulmasına ve kemik kırılganlığına yol açar $(1,2)$. Hastalarda travma veya spontan oluşan kırıklar içinde en sık görüleni vertebra deformiteleridir. Ayrıca kemik üzerine binen yük artarsa kemik kırılabilir. En sık görülen çökme kırıkları omurun ön kısmının çöktüğü kırık tipleridir. Çökme kırıkları kaza ve travmalara bağlı olarak oluşabileceği gibi, kemik erimesi ya da stres kırıkları şeklinde de kendiliğinden gelişebilir. Eğer omurga üzerine binen yük artarsa 0 zaman omurga korpusunun orta ve arka kısmında da çökme oluşur. Çökmenin artması ile patolojik açılanma ile birlikte kifoz açısı da artmış olur (3).

Torasik ve lomber kompresyon kırıklarının tedavisi, sonuçta oluşan kifoz ve vertebra yüksekliği kaybının derecesine dayanır. Bu nedenle radyografik inceleme kifozdaki ilerlemeyi anlamamızı ve yeterli kararlar almamızı sağlar. Kifoz açısı vertebral korpusun çökmesini değerlendirmek için önemli bir markırdır (4).

Kırığın sonucunda gelişen kifoz erken dönemde ağrıdan dolayı hareket kısıtılığı, fiziksel ve fonksiyonel bozukluklar meydana getirirken, ilerleyen dönemde ve çökmenin ilerlediği olgularda ise felce kadar gidebilen nörolojik bulgularla kendini gösterebilir (5).

Omurlarının yalnızca ön kısmında çökme olan, yatak istirahati ve korse ile tedavi edilebilen hastaları, normal fizyolojik ağırlıkları ile zarar görmeyecek sağlıkı bir omurga kazandırıp, hastaları en kısa zamanda eski yaşamlarına ağrısız olarak döndürmek için tanı ve takipte kullanımak üzere radyolojik ve biyokimyasal araştırmalar yapılmış olsa da, bu çalışmalar istenilen düzeylerde değildir $(6,7)$.

Kemiğin oluşumunu etkileyen birçok faktör var iken, kemiğin yapısını esas olarak protein, albümin ve kalsiyum oluşturmaktadır. Amacımız, çökme kııı̆ı olan hastalarda radyolojik olarak kifoz açısını değerlendirerek, kemiğin oluşumunu etkileyen biyokimyasal parametrelerden kan total protein, albümin ve kalsiyum'un kemik üzerine olan etkilerini değerlendirmek istedik.

\section{Materyal ve Metod}

Çalışmamızda Haziran 2014 ile Aralık 2018 tarihleri arasında takipli 70 torakolomber çökme kırık olgusu retrospektif olarak değerlendirildi. Herhangi bir yaş ve cinsiyet ayrımı yapılmadı. Multipl çökme kırıkları, enfeksiyonlar ve metastazlar çalışma dışında bırakıldı. Çalışma için yerel etik komiteden onay alınmıştır.

Bilgisayarlı tomografi görüntüleri 64-detector-row PhilipsBrilliance CT scanner (Philips Medical Systems, Cleveland, $\mathrm{OH}$; collimation $0.625 \mathrm{~mm}$, pitch $1,0.75$ s/cycle scan speed, slice thickness $2 \mathrm{~mm}$, slice increment $0.45 \mathrm{~mm}$, dose $250 \mathrm{mAsand} 120 \mathrm{kV}$ ) ve 16-detector Toshiba Activion V3.00 CT scanner (Toshiba Medical Sytems, Tokyo, Japan ); collimation $0.625 \mathrm{~mm}$, pitch 1, 0.75 s/cycle scan speed, slice thickness $2 \mathrm{~mm}$, slice increment $0.45 \mathrm{~mm}$, and dose $200 \mathrm{mAsand} 120 \mathrm{kV}$ ) ile elde edildi. Olguların BT görüntüleri radyolojik iş istasyonunda (INFINITT; Infinitt Healthcare, Seoul, Korea), beyin cerrahisi uzmanı (H.Ö), fizik tedavi uzmanı (M.B) ve spinal BT konusunda deneyimli iki uzman radyolog (S.H), (MA.D) tarafından değerlendirilerek, ölçümler yapıldı. Her bir olgunun yaş, cinsiyet, çökme kırı̆ının düzeyi, kan biyokimyasal değerleri [total protein (gr/dl), albumin (gr/dl), kalsiyum (mg/dl)] ve spinal BT (bilgisayarlı tomografi) kesitleri değerlendirilerek kifoz açısı (derece)(4) hesaplandı (Şekil 1).

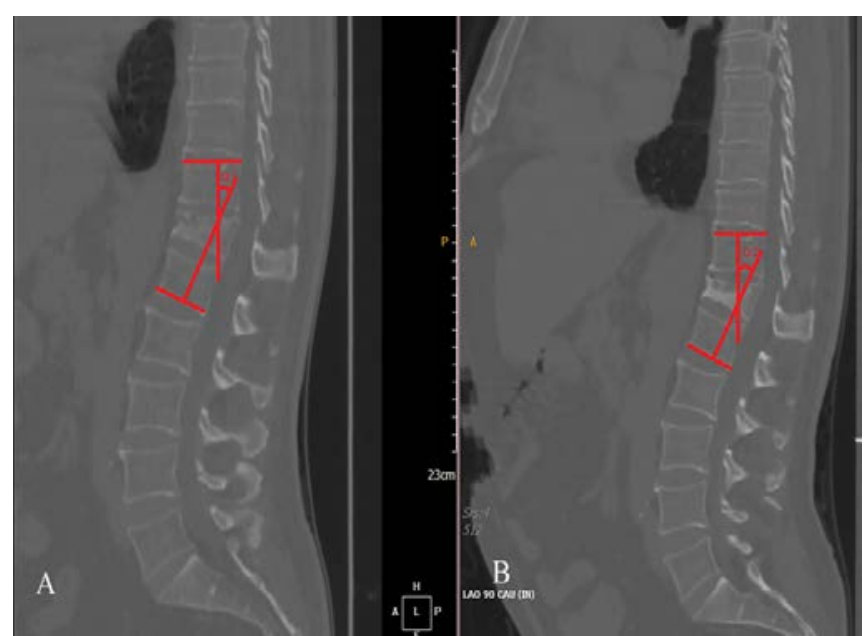

Şekil 1. 58 yaşındaki erkek hastanın torakal 12 çökme kırığı bilgisayarlı tomografi görüntüsü.

A. Başlangıç dönemi kifoz açısı,

B. 6 ay sonraki kifoz açısı ölçümü.

Veriler ortalama \pm standart sapma (min-max) olarak sunulup, verilerin analizi için SPSS 18 (Chicago, Illinois, ABD) programı kullanıımışır. Araştırmadan elde edilen verilerle cinsiyetler arasında farklılık olup olmadığını belirlemek için bağımsız örneklem $t$ testi, başlangıç ile 6 . ay kifoz açısı ve biyokimyasal değerler arasında istatistiksel anlamılıık için bağımlı örneklem $t$ testi yapıldı. Yaş ve kan biyokimyasal değerlerinin başlangıç ve 6 . ay değerleri aralarında korelasyon gösterip göstermediğini belirlemek için pearson korelasyon analizi yapııdı. $P<0.05$ olan değerler anlamlı kabul edildi.

\section{Bulgular}

Çalışmamızda Haziran 2014 ile Aralık 2018 tarihleri arasında takipli 70 torakolomber omurga çökme kırık olgusu retrospektif olarak değerlendirildiğinde vakaların $41 \mathrm{i} i$ $(53,68 \pm 19,27)$ erkek, 29'। $(61,1 \pm 16,87)$ kadındı. Ortalama yaş 56,76 $\pm 18,56$ (14-98) idi. Erkek ve kadınlar arasında erkeklerin sayısı fazla olmakla birlikte, istatistiksel açıdan karşılaştırdığımızda anlamlılık bulunmadı $(p=0,09)$. Ileri 
yaşlarda ise kadınlarda sık görülmekteydi (Şekil 2 A, B). Torakolomber çökme kııkları sıklıkla T11-L2 düzeyinde görüldü (Şekil 2C).

Vakaların başlangıç[1] kifoz açıları $(10,56 \pm 6,97)$ ile altıncı ay[2] kifoz açıları $(12,25 \pm 7,47)$ karşılaştıııldığında, istatistiksel açıdan anlamlı bulunurken $(p<0.001)$; total protein1 $(6,86 \pm 1,01)$ ile total protein2 $(6,82 \pm 0,75)$ düzeyi $(p=0,70)$; albümin1 $(3,59 \pm 0,59)$ ile albümin2 $(3,55 \pm 0,57)$ düzeyi $(p=0,43)$; kalsiyum1 $(9,10 \pm 0,65)$ ile kalsiyum2 $(8,99 \pm 0,7)$ düzeyi istatistiksel açıdan anlamlı bulunmadı $(p=0.19)$ (Şekil 2D).
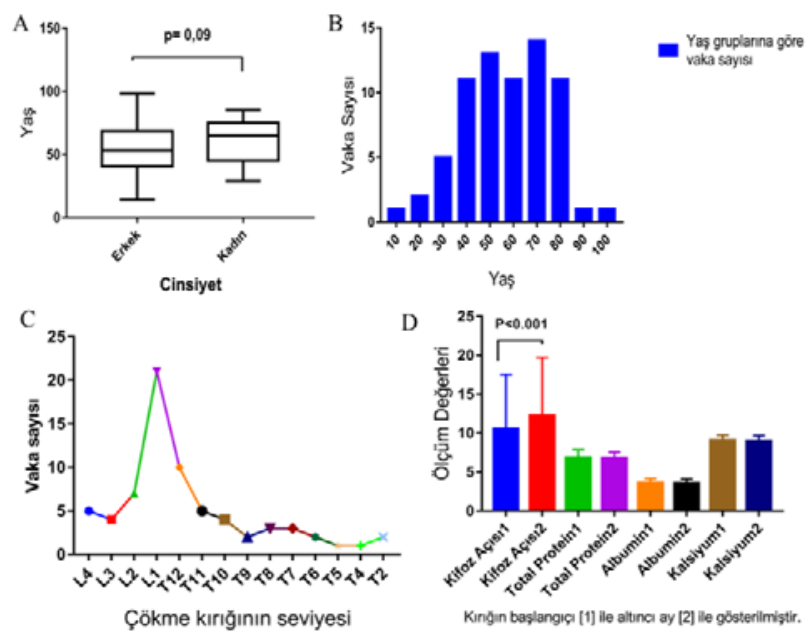

Şekil 2.

A. Cinsiyet açısından çökme kırı̆̆ının değerlendirimesi, $p=0,09$. (bağımsız örneklem t testi)

B. Yaş gruplarına göre dağı̆ımı.

C. T (torakal) ve L (lomber) çökme kırıklarının seviye olarak dağılımı.

D. Çökme kırığın başlangıç ve 6 . ay sonraki değerlerinin istatistiksel karşılaştıııması (bağımlı örneklem t testi).

Kifoz açıSı, yaş, total protein, albumin, kalsiyumun başlangıç ve altıncı ay değerleri kendi aralarında karşılaştırıldığında; kifoz açısı ile diğerleri arasında herhangi bir korelasyon görülmedi. Başlangıç değerleri albumin-total protein $(r=0,586 ; p<0,001)$, total protein-kalsiyum $(r=0,61 ; p<$ $0,001)$, albumin-kalsiyum $(r=0,56 ; p<0,001)$ arasında pozitif yönde anlamlı korelasyon görülürken, albumin-yaş ( $r=$ $-0,285 ; p=0,016$ ) arasında negatif yönde anlamlı korelasyon görüldü. Altıncı ay değerleri albumin-total protein ( $r=$ $0,66 ; p<0,001)$, total protein-kalsiyum ( $r=0,487 ; p<0,001$ ), albumin-kalsiyum ( $r=0,495 ; p<0,001)$ arasında pozitif yönde anlamlı korelasyon görülürken, albumin-yaş ( $r=$ $0,229 ; p=0,057)$ arasında negatif yönde korelasyon görüldü (Şekil 3).

\section{Tartışma}

Vertebra kompresyon fraktürü dünya genelinde milyonlarca insanı etkileyen önemli toplum sağlığı sorunlarından birisidir. Toplumlar üzerinde fiziksel, sosyal ve ekonomik etkileri vardır (8). Bu fraktürler yaşam kalitesini etkileyebilecek bel ağrılarına ve hatta ilerleyerek sakatlık oranlarının artmasına neden olabilir $(9,10)$. Omurga deformiteleri ve kırıklarında belli düzeyde omurun ön kısmının çöktüğü kırıklar sık görülür. Eğer zaman içerisinde omur üzerine binen yük artarsa, bu durumda omurun orta ve arka kısmında da çökmeler oluşur. Çöken parçalar omurilik kanaIına doğru ilerleyerek omuriliği zedeleyebilir. Omurga üzerine binen yükler daha da artar veya travmatik kuvvet uygulanırsa o zaman omurga çökmesi ile birlikte bu omurları bir arada tutan disklerde, ligamentlerde ve eklemlerde ciddi yaralanmalar olabilir. Bu durumda iki omurun birbiri ile bağlantısı koparak omurganın çökmesi ile birlikte omurga çıkığı oluşmuş olur $(11,12)$.
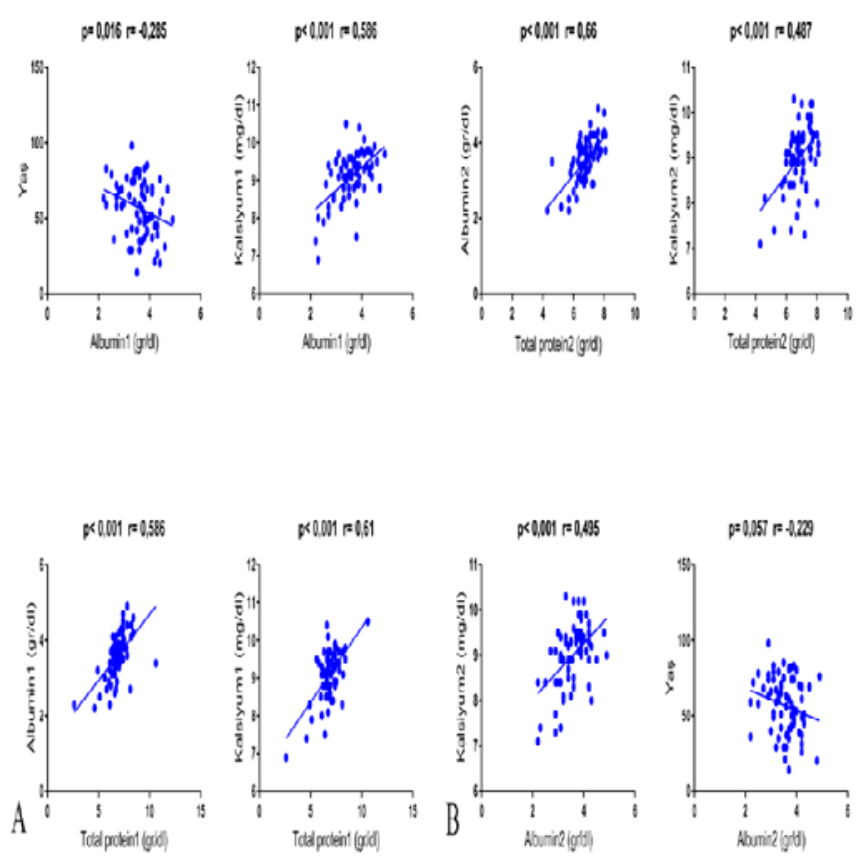

Şekil 3.

A. Çökme kırı̆ının başlangıç ve

B. 6 ay sonraki değerlerin istatistiksel karşılaştırıması (Pearson korelasyon testi).

Vertebra çökme kırıkları etkili bir şekilde ve zamanında tedavi edilmezse kronik ağrı, torakal ve lomber kifoz, komşu vertebra kırıkları, akciğer kapasitesinde azalma ve fonksiyon kaybı, uyku bozuklukları gibi ek sorunlar oluşabilmektedir $(13,14)$.

Kemiklerdeki çökmenin en sık sebebi mineral dengesinin bozulması sonucu kemiklerin yük taşıma ve dayanıkııık özelliğinin azalmasıdır. Buna bağlı kemiğin frajil yapısı ve çöken kemiğin patolojik açllanması artmaktadır (15). Başka bir sebep travmaya bağlı vertebra korpusunda hücresel düzeyde enflamasyon ve ödem ile oluşur. Bunu da 0 bölgede apopitotik hücre ölümü ve nekrozu tetikler (16). Kaneda ve ark. (17) omurga kompresyon fraktürlerinde çö- 
ken korpusta, iskemiye sekonder nekroz geliştiğini bildirmişlerdir. Ayrıca çökme artı̧̧ının tekrarlayan mikro travmalar ve iskemine deniyle ortaya çıkan kırılgan kemik yapısından da kaynaklanabileceğini ileri sürmüşlerdir (18). Hastalarda travma nedeniyle gelişen kırıklar içerisinde sıklıkla oluşanı vertebra deformiteleridir. Bu oluşum ise hastalarda kifoz, hareket kısıtılığı ve ağrı gibi belirgin fiziksel ve fonksiyonel bozukluklar meydana getirir.

Torasik ve lomber kompresyon kırıklarının tedavisi, oluşan kifoz ve vertebra yüksekliği kaybının derecesine dayanır. Bu nedenle radyografik inceleme kifoz ve skolyozdaki ilerlemeyi anlamamızı ve gerekli kararlar almamızı sağlar. Bu vertebralardaki korpusun çökme artışının değerlendirilmesinde kifoz açısı önemli bir parametredir $(4,19)$.

Yaptığımız çalışmada çökme kıı̆ı̆ı olan hastaların başlangıç ve altıncı aydaki kifoz açıları ölçülerek değerlendirildi ve istatistiksel açıdan anlamlı bulundu.

Kemik yapısının önemli bileşenlerinden olan total protein, albumin ve kalsiyumdan oluşması nedeniyle, kandaki total protein, albumin ve kalsiyum değerlerine bakıldı, kifoz açıları ile karşılaştırılı. Aralarında istatistiksel anlamlıık bulunmadı.

Bunun yanında kan biyokimyasal değerlerindeki total protein, albumin ve kalsiyumun başlangıç ve altıncı aydaki değerleri istatistiksel açıdan kendi aralarında karşılaştırıldığında anlamlı pozitif korelasyon göstermiştir.

Vertebral kompresyon kırıkları ileri yaşlarda günlük aktiviteleri ve travmalarla ilgili yükleri destekleyemeyecek kadar zayıf olduğundan daha sık rastlanmaktadır (20). Yaptığımız çalışmada da vertebral kompresyon kırıkları ileri yaşlarda daha sık görülmekteydi. Yaşlılar da kemiğin frajil bir yapıya sahip olması kemik yapısında bulunan protein, albumin ve kalsiyumun az olmasına bağlıdır $(1,2)$. Yaş ile kandaki total protein, albumin ve kalsiyum değerleri karşılaştırıldığında sadece albumin ile anlamlı negatif korelasyon görüldü.

Vertebra kompresyon fraktürleri erkeklerde daha sık görülmesine rağmen 65 yaş üzerinde kadınlarda daha sık görülmüştür (21). Yaptığımız çalışmada vertebral kompresyon kırıkları ileri yaşlarda kadınlarda daha sık görüldü.

Torakolomber omurga anatomisi ve biyomekanik özelliklerinden dolayı kırıkların büyük bir kısmı torakolomber bileşke bölgesinde görülür. Çok merkezli yapılan çalışmalarda torakolomber kırıklar en sık (Torakal 11-Lomber 2) düzeyinde olduğunu ortaya koymuştur $(22,23)$. Literatürle uyumlu olarak bizim çalışmamızda da çökme kıııları en sık bu düzeylerde görüldü.

Sonuç olarak çalışmamızda nörolojik defisiti olmayan torakal ve lomber bölge omurga çökme kırıklarında zamanla kifoz açısının arttığı bunun yaş ve kan biyokimyasal değerlerinden total protein, albumin, kalsiyum ile ilişkili olmadığı gördük. Çalışmamız vertebral kompresyon kırıklarında radyolojik ve bu biyokimyasal parametrelerin değerlendirildiği illk çalışmadır.

\section{Kaynaklar}

1. Kunutsor SK, Voutilainen A, Whitehouse MR, Seidu S, Kauhanen J, Blom AW, et al. Serum Albumin and Future Risk of Hip, Humeral, and Wrist Fractures in Caucasian Men: New Findings from a Prospective Cohort Study. Med Princ Pract. 2019;28(5):401-9.

2. Prestwood KM, Raisz LG. Prevention and treatment of osteoporosis. Clinical Cornerstone. 2002;4(6):31-41.

3. Shimizu K, Nakamura M, Nishikawa Y, Hijikata S, Chiba K, Toyama Y. Spinal kyphosis causes demyelination and neuronal loss in the spinal cord: a new model of kyphotic deformity using juvenile Japanese small game fowls. Spine. 2005;30(21):2388-92.

4. Seo DH, Oh SH, Yoon KW, Ko JH, Kim YJ, Lee JY. Risk Factors of New Adjacent Compression Fracture after Percutaneous Vertebroplasty: Effectiveness of Bisphosphonate in Osteoporotic or Osteopenic Elderly Patients. Korean J Neurotrauma. 2014;10(2):86-91.

5. Kim KT, Suk KS, Kim JM, Lee SH. Delayed vertebral collapse with neurological deficits secondary to osteoporosis. Int Orthop. 2003;27(2):65-9.

6. Zhao $\mathrm{P}$, Wang $\mathrm{S}$, Zhou $\mathrm{Y}$, Zheng $\mathrm{H}$, Zhao G. MicroRNA-185 regulates spinal cord injuries induced by thoracolumbar spine compression fractures by targeting transforming growth factor- $\beta 1$. Exp Ther Med. 2017;13(3):1127-32.

7. Eschler A, Rocktaeschel P, Herlyn PKE, Roesner JP, Martin H, Vollmar B, et al. Intrabody application of eptotermin alpha enhances bone formation in osteoporotic fractures of the lumbarspine; however, fails to increase biomechanical stability- results of an experimental sheep model. Growth Factors. 2015;33(4):290-7.

8. Johnell O, Kanis JA. An estimate of the world wide prevalence and disability associated with osteoporotic fractures. Osteoporos Int. 2006;17:1726-33.

9. Ross PD. Clinical consequences of vertebral fractures. Am J Med. 1997; 103:30-42.

10. Nevitt MC, Ettinger B, Black DM,Stone K, Jamal SA, Ensrud K, et al. The association of radiographically detected vertebral fractures with back pain and function: a prospective study. Ann Intern Med 1998;128:793-800.

11. Holdsworth F. Fractures, dislocations, and fracture-dislocations of the spine. J Bone Joint Surg Am. 1970;52:1534-51.

12. James KS, Wenger KH, Schlegel JD, Dunn HK. Biomechanical role of the thoracolumbar ligaments of the posterior ligamentous complex: a finite element study. World Neurosurg. 2018;112:125-133.

13. Schlaich C, Minne HW, Bruckner T, Wagner G, Gebest HJ, Grunze $\mathrm{M}$, et al. Reduced pulmonary function in patients with spinal osteoporotic fractures. Osteoporos Int 1998;8:261-7.

14. Silverman SL. The clinical consequence of vertebral compression fracture. Bone 1992;13:27-31.

15. Küçükoğlu S. Osteoporoz. In: Aksoy K. Temel Nöroşirurji. 1st ed. Ankara: Türk Nöroşirurji Derneği Yayınları; 2005:1100-9.

16. Ozevren $\mathrm{H}$, Deveci E. Neuroprotective Effects of Lamotrigine on Brain Injury in Rats. AQCH 2017;39(3):163-174.

17. Kaneda K, Asano S, Hashimoto T, Satoh S, Fujiya M. The treatment of osteoporotic-posttraumatic vertebral collapse using the Kaneda device and bioactive ceramic vertebral prosthesis. Spine 1992;17:295303.

18. Matzaroglou C, Georgiou CS, Panagopoulos A, Assimakopoulos K, Wilke HJ, Habermann B, Panos G, Kafchitsas K. Kummell's disease: Clarifying the mechanisms and Patients' inclusion criteria. Open Orthop J. 2014:8:288-97.

19. Pradhan BB, Bae HW, Kropf MA, Patel VV, Delamarter RB. Kyphoplasty reduction of osteoporotic vertebral compression fractures: correction of local kyphosis versus overall sagittal alignment. Spine 2006;31(4):435-41.

20. Kim CH, Choi YJ, Hwang JK, Kim KH, Lee JH, Song JS. Long term outcome of vertebroplasty in the treatment of osteoporotic compression fracture. J Korean Neurosurg Soc 2005;12:69-74. 
21. Burge R, Dawson-Hughes $B$, Solomon $D H$, Wong JB, King A, Tosteson $A$. Incidence and economic burden of osteoporosis-related fractures in the United States, 2005-2025. J. Bone Miner. Res. 2007;22:465475.

22. Gertzbein SD. Scoliosis research society: multicenter spine fracture study. Spine 1992;17:528-40.

23. Deng H, Li Y, Zhou J, Wang X, Du J, Gao W, Hao D. Therapeutic efficacy of Transpedicular Intracorporeal cement augmentation with short segmental posterior instrumentation in treating osteonecrosis of the vertebral body: a retrospective case series with a minimum 5-year follow-up. BMC Musculoskelet Disord. 2019;20:305. 